\title{
The genus Pleuroxus Baird, 1843 (Crustacea: Anomopoda: Chydoridae) in Cameroon, Central-West Africa.
}

\author{
G.Y. Chiambeng 1 , H.J. Dumont $2 *$
}

${ }^{1}$ Research Station for Fisheries and Oceanography, PMB 77 Limbe, Cameroon.

${ }^{2}$ Laboratory of Animal Ecology and Zoogeography, Department of Biology, State University of Gent, Ledeganckstraat 35, B-9000 Gent, Belgium.

\begin{abstract}
We studied the genus Pleuroxus (including Picripleuroxus) of the rainforests of Cameroon, making extensive use of trunk limb morphology. Six species were found. Pleuroxus aduncus, P. toumodensis, P. unispinus, Pleuroxus cf similis, P. laevis and $P$. denticulatus show differences in postabdomen, but also in the inner distal lobes (IDL) and endites (E1-E3) of the first trunk limb (P1), endopodites (EN) of the second limb (P2), exopodites (EX) and outer spines of the endopodite of the third limb (P3), and epipodites (EP)/ endopodites (EN) of the fourth and fifth limbs (P4 \& P5). These limbs, previously believed to be structurally similar, are thus seen to be built according to a strongly conserved plan, yet with specific differences. The differences found do not coincide with Frey's subdivisions of the genus based on external characters. Consequently, we cannot confirm the existence of a (sub)genus Picripleuroxus. Four species are shared with temperate to continental and subarctic Eurasia. Pleuroxus cf. similis is closest to a species originally described from Chile, and subsequently reported from Central Asia and Australia. It remains insufficiently characterized. Pleuroxus toumodensis is an African endemic, typical of gallery forests along rivers (from the Niger to the Nile). It is now also found in true rainforest waters. Pleuroxus unispinus was previously known only from Australia.
\end{abstract}

Keywords : Cladocera, morphology, rainforest, Pleuroxus, trunk limbs.

\section{Introduction}

The chydorid genus Pleuroxus (including Picripleuroxus, which we regard as a synonym) was to date considered rare in the humid tropics (Fernando 1980). Most species were believed to be typical of the Holarctic region, with few species recorded for tropical South East Asia and South America (Frey 1988, 1993a, 1993b, Smirnov 1971, 1996, Alonso 1996, Chiambeng 2004) beside quite a few from Australia and a number of subantarctic islands (Frey 1993). But previous studies had been based on traditional methods of external morphology, with little information on trunk limb structure (Smirnov 1971, 1996). More recent attempts to figure these limbs have mostly been limited to the outer and inner distal lobes (ODL/IDL)

* Corresponding author : E-mail : Henri.Dumont@UGent.be of the first limb (P1) and, inconsistently, to some other limb structures (Frey 1988, 1993, Alonso 1996, Smirnov 1996), although current standards require that the entire complement of limbs be figured (Dumont \& Negrea 2002). Chiambeng (2004) identified seven species of Pleuroxus from the world rainforests : Pleuroxus aduncus (Jurine 1820), Pleuroxus similis (Vavra 1900), Pleuroxus denticulatus Birge 1879, Pleuroxus unispinus (Henry 1922), Pleuroxus toumodensis Brehm 1934, Pleuroxus striatus (Schoedler 1863) and Pleuroxus laevis (Sars 1862). Six of these are present in the Cameroon rainforest. The present paper describes the representatives of the genus Pleuroxus from the rainforest of Cameroon, combining external morphology with trunk limb data.

\section{Material and methods}

In an exhaustive survey, 724 qualitative plankton samples were collected between September 1998-Mar- 
ch 2002 from the rainforests of Mt Cameroon, viz. the Korup National park and forest, the Southern Bakundu forest, the Campo-Maan \& Kribi forests, the South East forests (Dja \& Boumba-Bek), the Mbalmayo forest, the Douala-Edea forest, the Ebolowa and Yaounde regions and the Kupe-Manengouba and Mamfe regions, using plankton nets of mesh size $100 \mu$. All types of aquatic environment encountered (lakes, streams and rivers, ephemeral and permanent ponds and pools, swamps, water collected in rock and tree holes and even in fallen fruit cavities and wet mosses) were sampled. Several species-rich areas were re-sampled three or four times, in different periods of the year. Plankton was collected by towing a net of $20 \mathrm{~cm}$ aperture, attached to a nylon rope, or mounted on an iron rod, through water with or without vegetation. We specially focused on the littoral area. In small ponds, about half the pond volume was filtered, while in stone or fruit cavities, the entire volume of water was passed through the plankton net. In large swamps or lakes, several net tows were taken, making sure that all major zones of these water-bodies were adequately covered. An estimated minimum of 4-500 liters of water per site were filtered. Sorting and identification of the entire sample (not of subsamples only!) in the laboratory was done using a Wild stereo zoom dissection microscope and drawings were made with the help of a camera lucida.

\section{Results}

We recorded Pleuroxus aduncus (Jurine, 1820), Pleuroxus denticulatus Birge, 1879, Pleuroxus unispinus (Henry, 1922), Pleuroxus toumodensis Brehm 1934, Pleuroxus cf. similis (Vavra, 1900), and Pleuroxus laevis (Sars, 1862). In spite of the considerable collecting effort invested, all species were encountered in low to very low numbers. In all, exactly 23 specimens were found.

\section{Diagnostic characters of the genus Pleuroxus Baird, 1843.}

Pleuroxus s. 1. is one of about 18 genera of Chydorinae, several of which are entirely restricted to Australia, and with trunk limb morphology unknown or inadequately known. Among the morphologically better studied genera that bear an immediate relationship to Pleuroxus, we cite: Disparalona, Chydorus, Ephemeroporus, Paralona, and Alonella. All these share at least two trunk limb characters: a modified seta 6 on the exopodite of P3 (adorned with very long strong setules on the inner side of the seta; this character also found in Eurycercidae), and presence of two small protuberances, remnants of setae, basal to seta 4 of the exopodite of P5. Pseudochydorus in fact also shares these characters, and thus may be part of a monophyletic group, but is an otherwise highly specialized carrion-feeder with two specifically reduced setae on the exopodite of P4. The genera Dunhevedia and Dadaya differ in these characters, even if otherwise typically chydorine according to the criteria of Smirnov (1996). All in all, chydorine genera emerge as strongly conserved as far as trunk limb morphology goes, yet useful characters from a diagnostic and possibly phylogenetic point of view can be derived from a deeper scrutiny of their details. Here, we first sum up characters that appear typical of the genus. Next, we describe the six species found in the Cameroon rainforest.

\section{A. External characters}

Shape: Elongated oval or circular in lateral view. Postero-dorsal angle of valve much lower than maximum height; colour transparent whitish or yellowish.

Valves: Slightly convex; antero-ventral setae attached to valve edge and implanted in indentations, postero-ventral setae either at the edge or slightly submarginal; postero-ventral angle with denticles that continue as a row of spinules in the direction of the dorsal corner.

Head: Ocellus smaller than compound eye and located much closer to eye than to tip of rostrum; rostrum long, pointed downwards. Head pores situated at considerable distance, exceeding inter-pore distance, from posterior margin of head shield.

Labrum: with elongated convex anterior margin and pointed apex.

Antennae: First antenna longer than wide, with or without peg at base; in females with nine apical aesthetascs and one lateral seta. Second antenna: spine formula: 1-0-1/0-0-1; setal formula: 0-0-3/1-1-3.

Postabdomen: Of average length or short, elongated and slightly bent with concave post-anal margin in $\mathrm{Pi}$ cripleuroxus, convex or straight margin in Pleuroxus. Post-anal margin with spines, sometimes extending to anal section. Lateral surface with row of fascicles extending to anal part. Claw with two basal spines.

\section{B. Trunk limb characters}

Note. The five pairs of trunk limbs (P1-P5) of the chydorinae are variously oligomerized (segments of the original exopodites and endopodites, including endites, are fused). An exopodite and epipodite are usually well individualized (except sometimes on P1). The inner part of a leg, here called endopodite for simplici- 
ty, may or may not be homologous to a true endopodite; it may, in fact, represent the fusion of an endopodite with any of the five original endites, as still present in the Anostraca. Setae fringing the exo- and endopodites, including any filter combs, are counted from the outside to the inside.

Trunk limb 1 (P1): Outer distal lobe (ODL) with one long, bi-segmented seta plus a small spine near base; inner distal lobe (IDL) with three setae, with relative lengths characteristic of species; two long bi-segmented setae, equal or unequal in length (permitting to separate species), finely setulated on one side; one seta may be slightly more robust than the other, but setae not claw-like (as in e.g. Chydorus). Third seta from as tiny as short seta of ODL tiny to almost as long as both long setae of IDL. Corm with about six rows of stiff, curved setules in front and ten long setae, arranged on three endites: endite 1 (E1) (ventral) with three setulated (8-10) setae of subequal length and one accessory spine seta; Endite (E2) with three setae (5-7), with middle one (6) longest of all, and relative lengths of S5 and S7 characteristic of species; a shorter accessory spine seta near base; endite (E3) with four bisegmented bilaterally setulated setae (1-4). An extra plumose seta (unnumbered) below E1; gnathobase with single seta; two ejector hooks (EH) and epipodite (EP) situated near base of limb.

Trunk limb 2 (P2): Exopodite (EX) barrel-shaped, with broad-based, apically implanted seta and eight scrapers (Sc. 1-8). All scrapers finely denticulated, rarely scraper four with slightly stronger spinules. Scrapers 1-2 the longest, often equally long; 3-4 decreasing in length, with 5 again longer, and 6-8 shortest and often of the same length. A series of 4-8 spinules at foot of scraper 1. Either no sensillae between scrapers, or sensillum between scapers 4-5 or 5-6. The part of the gnathobase (GT) between scraper 8 and apical elements convex, adorned with tuft of spine-setae and a distal spinule. First apical element long, stretched and plumose; middle hammer-shaped; third element bifurcated. Gnathobasic filter-comb with eight setae, all equally long, or setae 1 and 2 shortened.

Trunk limb 3 (P3): Exopodite (EX) rather elongated and squarish, with three external (1-3) and four distal (4-7) bi-segmented setae; Setae 1-3 of the same length, implanted in a V-shape. Seta four thickest and longest; length of fifth and sixth setae characteristic of species. Inner rim of seta 6 with 6-8 stiff, long setules (a character shared with all chydorine genera cited above, but also with primitive chydoroids such as Eurycercus and Acantholeberis). Among the Aloninae, Oxyurella also has this seta modified, yet here the long, stiff se- tules occur on the outer side of the seta. Seta 7 lined with shortened setules. Endopodite (EN) on external portion with two claw-like setae of species-specific length, two minute receptors, and a plumose seta. Internal portion in front with a row with four, more or less sigmoid stiff setae and an oblique placed, apically perforated receptor. Caudally, a comb of six plumose setae; gnathobase of three partially fused elements, and with a filter comb (FC) of eight plumose setae.

Trunk limb 4 (P4): Pre-epipodite lobe (PEP) marginally feathered; epipodite (EP) elongate, length of process characteristic of species; exopodite (EX) with seven marginal setae: setae 1 and 2 about same length; seta 3 longest, others with lengths decreasing towards endopodite; endopodite (EN) with external erect spine and three flaming torch-setae. Flaming torch setae usually erect, not strongly modified. A comb of four plumose setae on its back side. Gnathobase (GT) with cylindrical receptor, horse-tail seta with support-seta and a comb of six plumose setae.

Trunk limb 5 (P5): Pre-epipodite (PEP) marginally feathered; epipodite (EP) elongate, shape and length of process characteristic of species; exopodite (EX) with four setae in a $3+1$ arrangement, plus two internal «humps», representing resorbed setae (probably a synapomorphy of a whole series of chydorine genera); endopodite (EN) small, single lobed, elongated (typical length/width ratio 3:1), partially setulated and with one seta at foot; gnathobase (GT) with single long seta, usually (though not always) more strongly developed than adjacent endopodital seta; filter comb (FC) with four setae. One or more small receptors between filter comb and gnathobasic seta.

\section{Pleuroxus aduncus (Jurine 1820): Figs 1, 2.}

Material examined : three parthenogenetic females from the Dja river at Somalomo village (Dja forest reserve, south Cameroon, 15/08/99); one parthenogenetic female from a spring at entrance to Kuma village along road from Beboka village (Korup forest, southwest Cameroon, 13/06/99).

Diagnosis : dorsal outline of valves convex with slight concavity close to dorsal angle; postabdomen short and broad, with rounded dorso-distal margin, about nine spines on post-anal margin, distal ones single, proximal ones smaller and irregularly grouped; P1: seta 5 of E2 shorter than seta 7, P2: scrapers 1-6 of ENP2 decreasing in length; P4: flaming torches 2 and 3 of ENP4 with basal sensillum. 


\section{Description}

\section{A. External features}

Head (Figure 1 A): Eye rounded, about twice diameter from margin; ocellus about half size of compound eye, located about a third distance from eye to tip of rostrum; head-shield with two major head pores and two smaller pores close to each other about midway between; inter-pore distance only slightly less than post-pore distance.
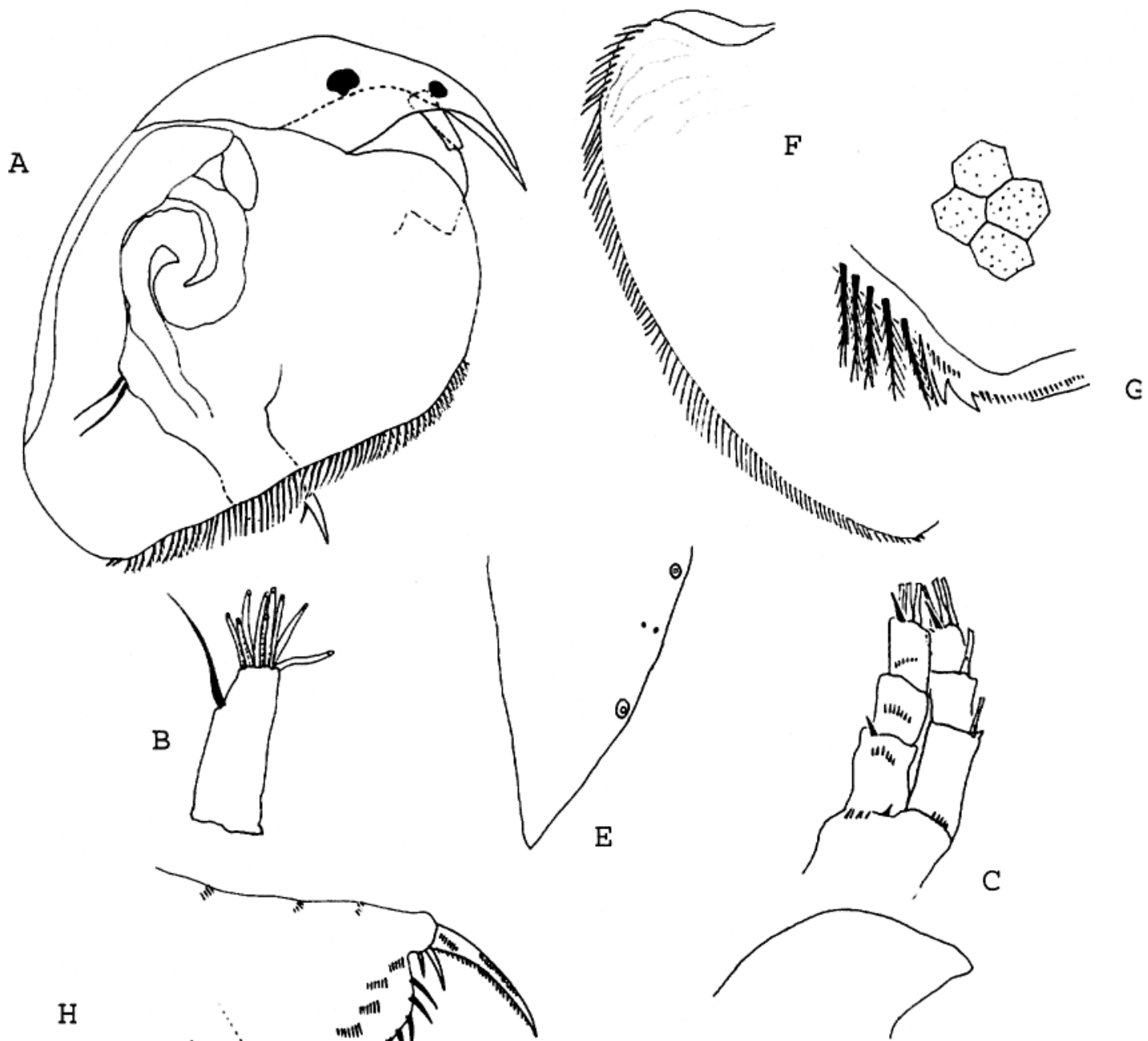

$\mathrm{D}$

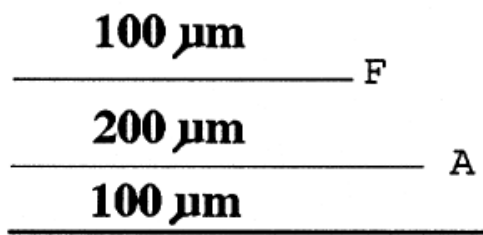

$B-E, G, H$

Fig. 1a. Pleuroxus aduncus. Female: habitus (A), first antenna (B), second antenna (C), labrum (D), headshield (E), ventral valve margin $(\mathrm{F})$, postero-ventral valve corner $(\mathrm{G})$, postabdomen $(\mathrm{H})$. 
Labrum (Figure 1 D): anterior margin weakly convex, ventral margin slightly concave and with pointed apex.

Antennules (Figure $1 \mathrm{~B}$ ): narrow, short, peg at base and nine terminal aesthetascs; lateral seta arising from an obscure notch at about a third distance from tip and about twice longest aesthetascs.

Antenna (Figure $1 \mathrm{C}$ ): as for genus

Valves (Figure 1 F): Dorsal margin convex, posterodorsal corner much lower than highest point of dorsal side; ventral setae 80-85 in number with 8-10 anteriormost sub-marginal, postero-ventral corner with two to three small denticles, width at base less than maximum width, directed anteriorly.

Postabdomen (Figure $1 \mathrm{H}$ ): Short and wide, postanal portion narrowing distally; anal teeth about nine in number; small, distal long and single; more proximal smaller, irregularly grouped and with smaller denticles; about twelve fascicles of short spinules laterally and three transverse rows of spinules ventrally.

Terminal claw (Figure $1 \mathrm{H}$ ): Short, gently curved to sharp tip; two basal spines present, first shorter and second about a third claw length; claw with faint setules along convex margin and pecten of spinules along concave margin.

Size: length: $0.35 \mathrm{~mm}$; height: $0.24 \mathrm{~mm}$.

\section{B. Trunk limbs}

Trunk limb 1 (Figures 1 I, J): Spine of IDL as long as first segment of seta 2; both setae of IDL subequal in length, but articulation of seta more basally situated than that of seta 2; seta 5 of E2 shorter than seta 7 .

Trunk limb 2 (Figure $1 \mathrm{~K}$ ): Scrapers 1-2 and 6-8 the same length. No sensillae at foot of scrapers. Last seta of filter-comb not shortened.

Trunk limb 3 (Figures $1 \mathrm{~L}, \mathrm{~N}$ ): Exopodite seta 5 only slightly shorter than seta 6; Outer portion of EnP3: both stiff setae the same length.

Trunk limb 4 (Figures 1 O, Q): Epipodite with vestigial process; En: external spine weakly developed, torches 2 and 3 with basal sensillum.

Trunk limb 5 (Figure $1 \mathrm{R}$ ): Epipodite with vestigial process; endopodital seta about as strongly developed as gnathobasic seta.

\section{Pleuroxus denticulatus Birge 1879 (Figure 2)}

Material examined: three parthenogenetic females from Mungo river at Mungo bridge along Tiko-Douala road, 18/04/02; two parthenogenetic females from Municipal Lake Mbalmayo, 13/07/98.
Diagnosis: Maximum height of valves about three times that of posterior margin; postabdomen long, with projecting dorso-distal corner, bearing four long slender denticles; P1: both setae of IDL strongly different in length; basal spine extending well beyond articulation of seta 1 ; Seta 7 not extending beyond seta 5 . P2 as in P. aduncus. P3 exopodite: articulation of seta 6 situated higher than that of seta 5 and articulation of seta 4 well distal of that of seta 6. P4 and P5 much as in $P$. aduncus.

\section{Description}

\section{A. External features}

Head (Figure 2 A): Rostrum long, curved backward; eye elongated to margin of headshield, about half diameter from margin; ocellus smaller than compound eye, located about a third distance from eye to tip of rostrum; headshield with two major and two minor pores; post-pore distance about twice inter-pore distance.

Labrum (Figure 2 D): Anterior margin strongly convex, with blunt tip; strongly concave immediately behind.

Antennules (Figure 2 B): Elongate, peg at base; ending slightly before middle of rostrum; directed downwards and with nine terminal aesthetascs; lateral seta arising from prominent tubercle at a third distance from tip about twice longest aesthetascs.

Antenna (Figure $2 \mathrm{C}$ ): as for genus.

Valves (Figure $2 \mathrm{G}, \mathrm{H}$ ): Ventral margin slightly convex, denticulate anteriorly and with 70-80 plumose setae; postero-ventral corner with two-three denticles, short row of spinules posterior to denticles; posterior margin slightly undulate, weak stripe pattern on valves.

Postabdomen (Figure 2 I): Elongated; anal teeth nine in number, thin distal longest and grouped at dorsodistal corner; followed each with 2-3 spinules and decreasing in length towards anus; eight fascicles of setules along lateral surface; pre-anal corner slightly projecting; three crescents of spinules on ventral margin.

Terminal claw (Figure 2 I): Long, adorned with two basal spines, distal one longer than proximal one and a quarter the length of claw; dorsal concave surface of claw with pecten of spinules.

Size: length: up to $0.37 \mathrm{~mm}$; height: up to $0.32 \mathrm{~mm}$. 

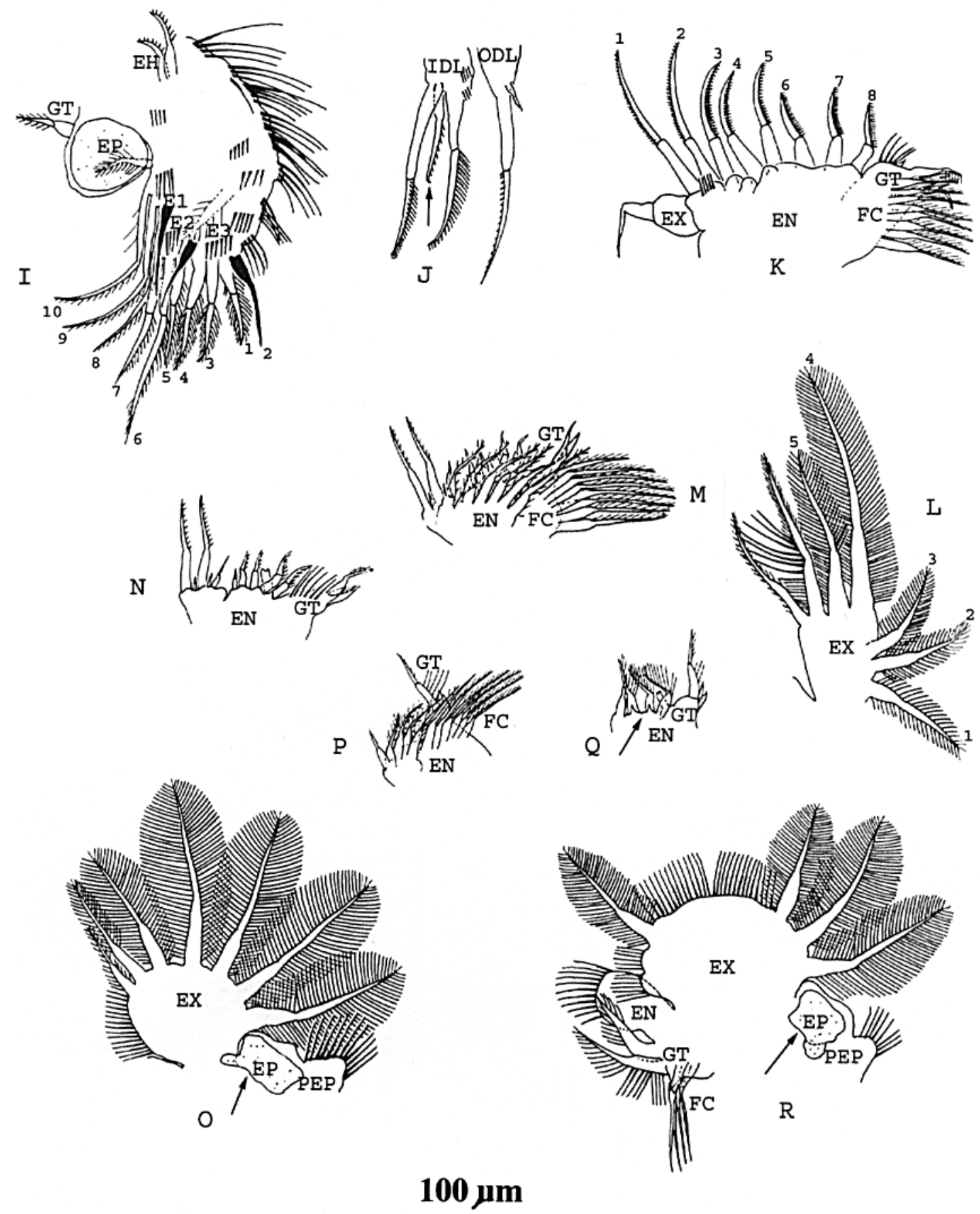

Fig. 1b. Pleuroxus aduncus. Female: first limb (I), ODL-IDL (J), second limb (K), third limb exopodite (L), endopodite (M, N), fourth limb, exopodite $(\mathrm{O})$, endopodite $(\mathrm{P}, \mathrm{Q})$, fifth limb $(\mathrm{R})$. 

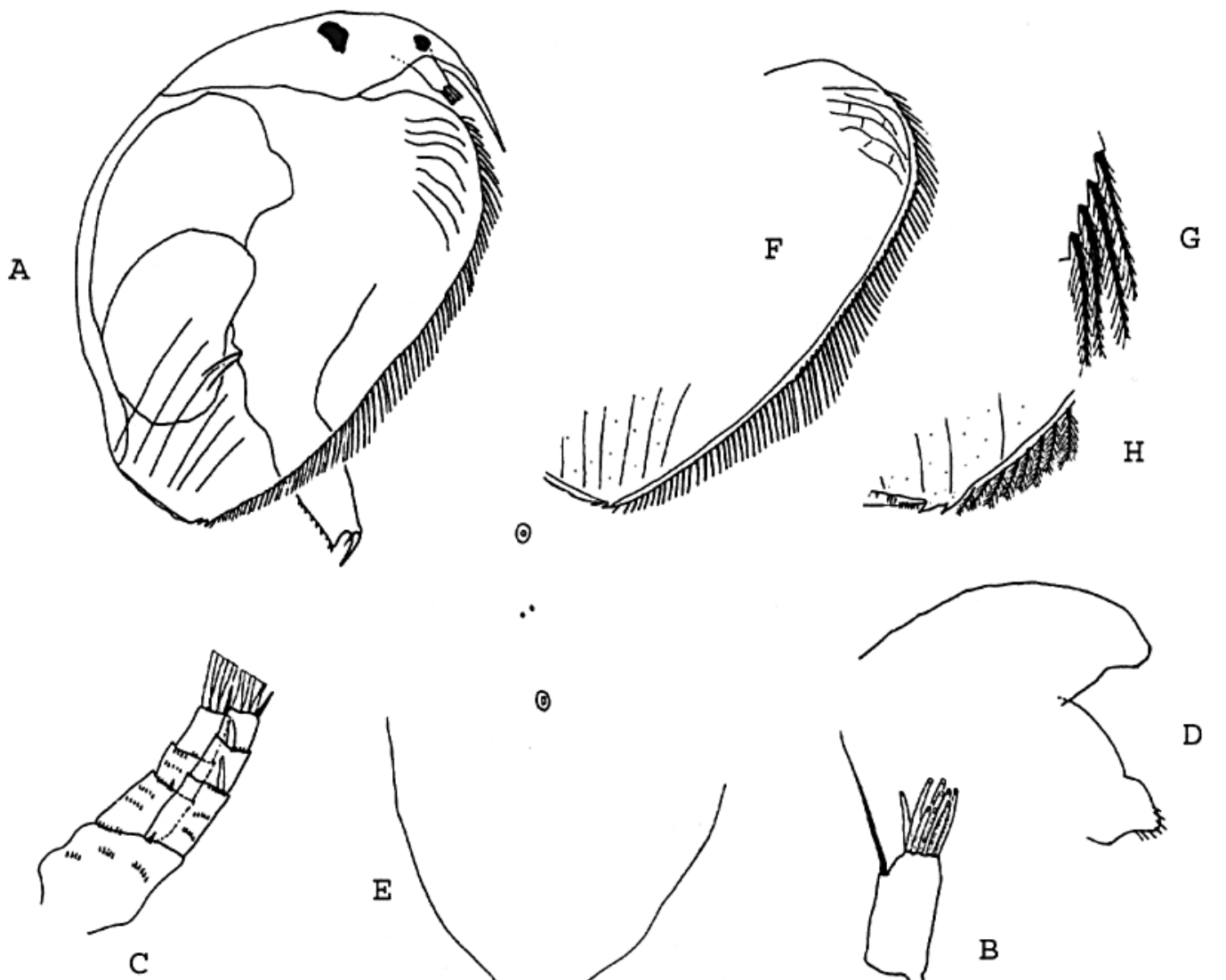

.

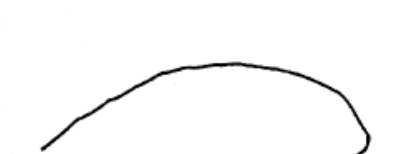

C
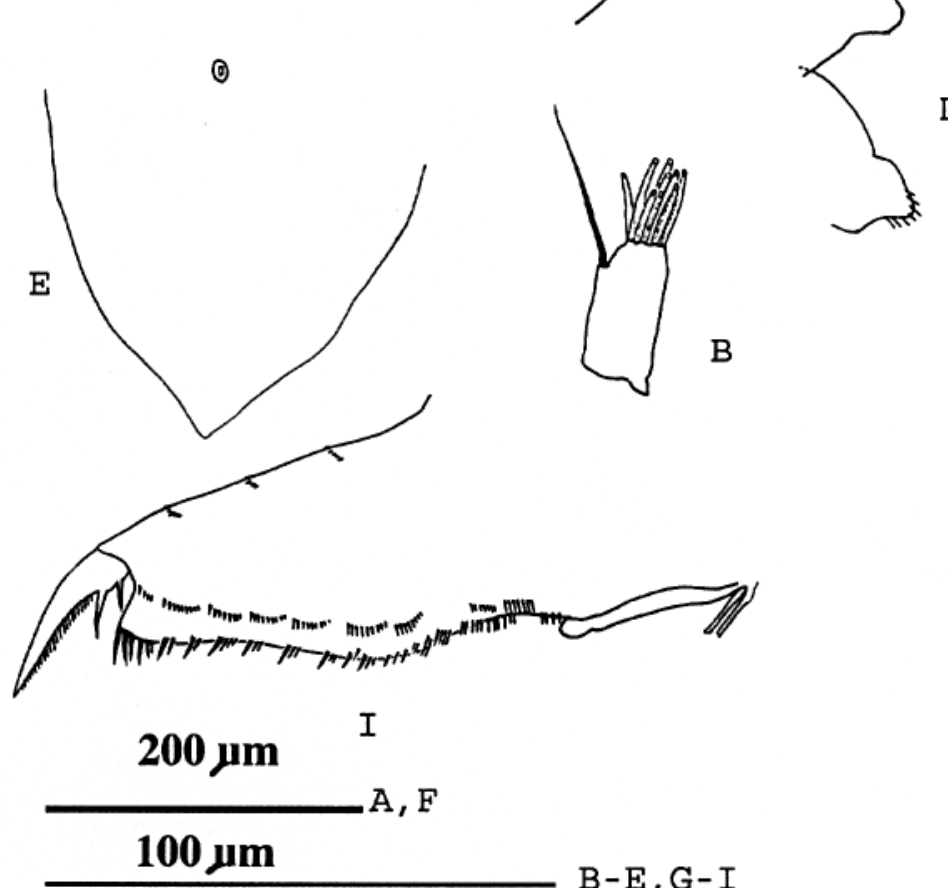

ventral margin $(F, G)$, postero-ventral corner $(\mathrm{H})$, postabdomen (I).

\section{B. Trunk limbs}

Trunk limb 1 (Figure $2 \mathrm{~J}, \mathrm{~K}$ ): Long setae of IDL rather strongly different in length. Spine at base of seta 2 extending well beyond articulation of seta 1. E2: Seta 7 not extending beyond seta 5 .
Trunk limb 2 (Figure $2 \mathrm{~L}$ ): Scraper proportions much as in P. aduncus, but Sc5 stronger. No basal sensillae.

Trunk limb 3 (Figure $2 \mathrm{M}, \mathrm{N}$ ): Exopodite seta 5 with articulation situated basad of that ofseta 6; articulation of seta 6 , in turn, basad to that of seta 4 . 

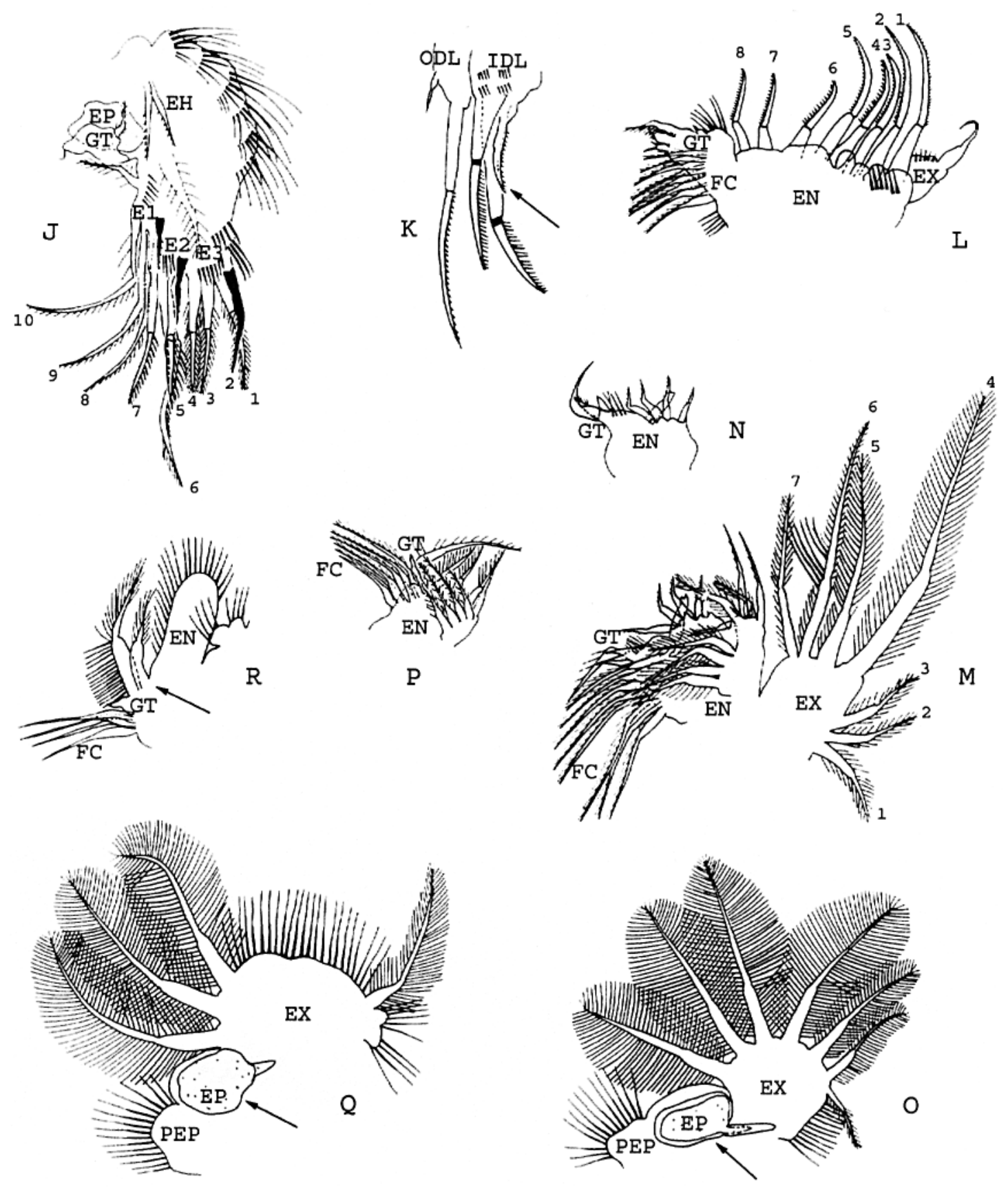

$100 \mu \mathrm{m}$

Fig. 2b. Pleuroxus denticulatus. Female: first limb (J), ODL-IDL (K), second limb (L), third limb (M), section of endopodite (N), fourth limb, exopodite $(\mathrm{O})$, endopodite $(\mathrm{P})$, fifth limb, exopodite $(\mathrm{Q})$, endopodite $(\mathrm{R})$. 
Trunk limb 4 (Figure 2 O, P): Epipodite with finger shaped process about as long as body of epipodite; other characters as for genus.

Trunk limb 5 (Figure 2 Q, R): Endopodital seta by far shorter than gnathobasic seta; other characters as for genus.

\section{Pleuroxus toumodensis Brehm 1934 (Figure 3)}

Material examined: One parthenogenetic female from stone cavity at light house of Debundscha village, Mt. Cameroon forest, 26/04/02; three parthenogenetic females from stream at entrance to Beboka village along road from Mundemba, Korup forest, 06/09/98.

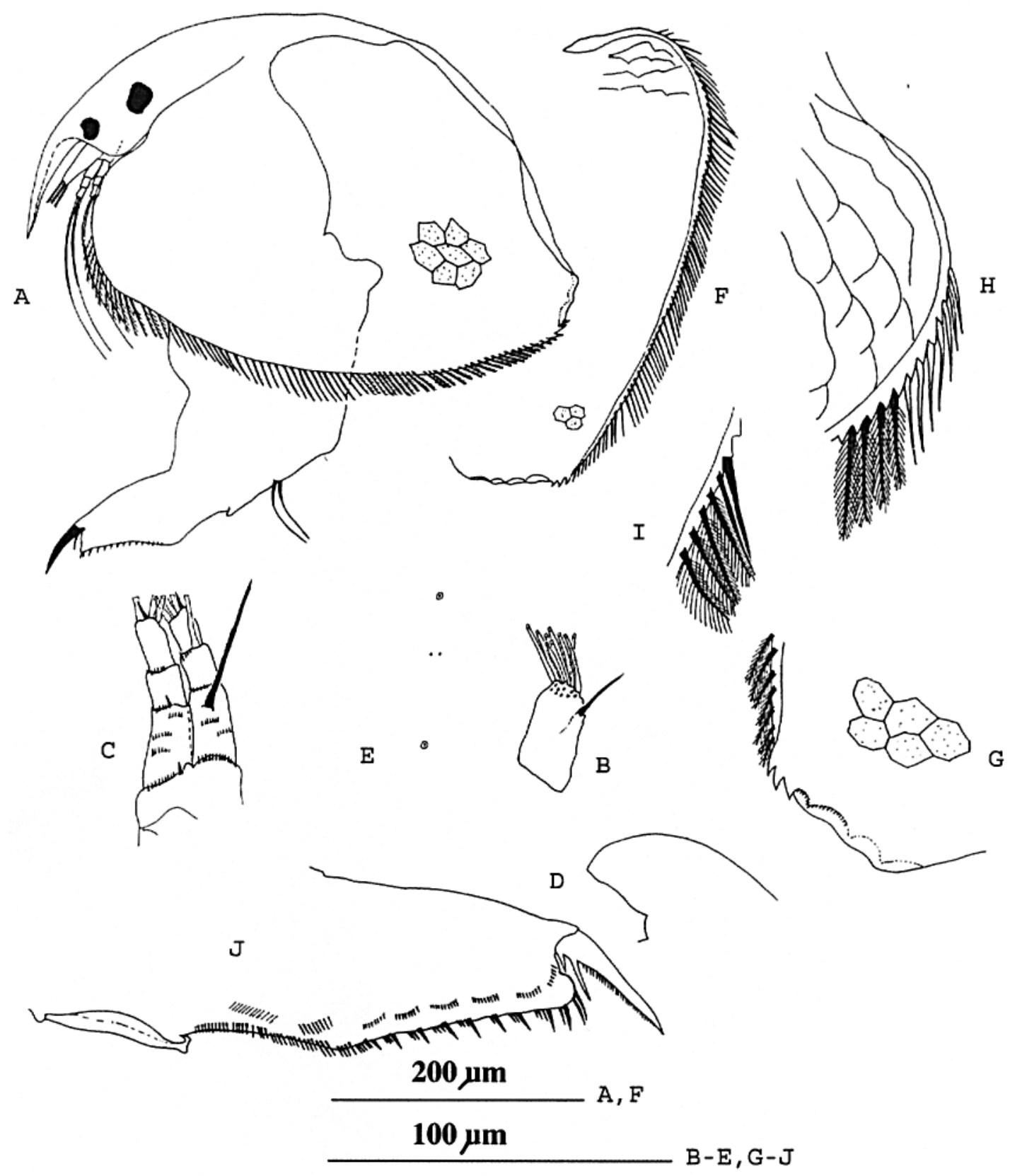

Fig. 3a. Pleuroxus toumodensis. Female: habitus (A), first antenna (B), second antenna (C), labrum (D), headpores (E), ventral margin $(F, I)$, postero-ventral corner $(\mathrm{G})$, antero-ventral corner $(\mathrm{H})$, postabdomen $(\mathrm{J})$ 
Diagnosis: Lateral seta of A1 inserted at about one fifth distance from tip; typically three denticles at postero-ventral corner of valves; posterior margin of valves strongly wavy; postabdomen with truncated distal corner; dorsal margin five times shorter than maximum height. P1: rows of spinules on corm strongly developed; spine of IDL just reaching articulation of long seta 2; both setae about equally long. P3: articulation of setae 5 and 6 of exopodite at same level. P4 and P5 with long fingers on epipodites.

\section{Description}

\section{A. External features}

Head (Figure 3 A): Rostrum long curved downward; eye rounded, about same length as diameter from headshield margin; ocellus smaller than compound eye, located about a quarter distance from eye to tip of rostrum; headshield with two major pores and two minor pores closer to anterior pore in between.

Labrum (Figure 3 D): Strongly convex anterior margin, rounded apex and weakly concave immediately after.

Antennules (Figure 3 B): Short elongated, directed downwards and ending around middle of rostrum, provided with nine terminal, subequally long aesthetascs; lateral seta arising from obscure lateral tubercle inserted at about one fifth distance from tip and only slightly longer than longest aesthetascs.

Antenna (Figure $3 \mathrm{C}$ ): as for genus.

Valves (Figure 3 F, H): With weak granulated hexagonal pattern; ventral margin with 70-80 plumose setae, implanted in indentations at anterior and middle portion while rim becomes smooth along posterior third; typically three denticles on postero-ventral corner; posterior margin strongly wavy; detached off the postero-ventral corner is row of spinules.

Postabdomen (Figure $3 \mathrm{~J}$ ): Slightly narrowing distally, truncated at distal end; anal teeth thin, grouped into ten groups of two or three spines that flank its sides; two strong teeth at dorso-distal corner, lateral surface with row of seven to eight fascicles of setules; pre-anal corner slightly projecting.

Terminal claw (Figure 3 J): Stoutly built, and with two basal spines, distal spine much longer and three times shorter than claw; claw with pecten of spinules along concave surface.

Size: length: $0.40 \mathrm{~mm}$; height: $0.23 \mathrm{~mm}$

\section{B. Trunk limbs}

Trunk limb 1 (Figure 3 K, L): Spine of IDL about half as long as first segment of seta 1 , just reaching articulation of seta 2; both setae about equally long. E3 and $\mathrm{E} 2$ as in $P$. denticulatus but seta 9 of E1 longer than seta 8; other characters as for genus.

Trunk limb 2 (Figure $3 \mathrm{M}$ ): Much as in P. denticulatus.

Trunk limb 3 (Figure 3 N, P): Seta 5 and 6 of exopodite constricted at same level; seta 4 constricted far distad of both. Seta adjacent to both spines of outer portion of endopodite relatively long.

Trunk limb 4 (Figure 3 Q, R): Epipodite with long process; other characters as for genus.

Trunk limb 5 (Figure $3 \mathrm{~S}$ ): Epipodite process longer than epipodite proper; endopodital/gnathobasic setae as in P. denticulatus.

\section{Pleuroxus unispinus (Henry 1922) (Figure 4)}

Material examined : One parthenogenetic female from Rengo river at Rengo Camp Korup forest, 02/09/98; two parthenogenetic females from tree cavity Pigmy Camp Boumba-Bek forest at Mikel village Boumba-Bek forest, 15/06/99; two parthenogenetic females from river Ndjo'o along road to Messama from Nyabesan, Campo-Ma'an forest, 07/08/01.

Diagnosis: Circular, postero-ventral margin of valve with blunt denticle; first eight spinules posterior to denticle long with first five barely projecting beyond posterior margin; P1: seta 5 shorter than seta 7 . Long IDL setae subequal in length; spine reaching to articulation of seta 2. P2: scraper 2 shorter than scr1 and scr 7 shorter than scrapers 6 and 8 . A receptor between scrapers 5 and 6 . Last seta of filter-comb shorter than others.

\section{Description}

\section{A. External features}

Head (Figure 4 A): Rostrum long, pointed downward; Eye elongated to margin of headshield, about half diameter from margin; ocellus smaller than compound eye, about a third distance from eye to tip of rostrum; headshield with two major and two minor headpores about midway; post-pore distance about one and a half times inter-pore distance.

Labrum (Figure 4 D): Triangular, with weakly convex anterior margin, and rounded apex; concave immediately after.

Antennules (Figure 4 B): Ending slightly before 


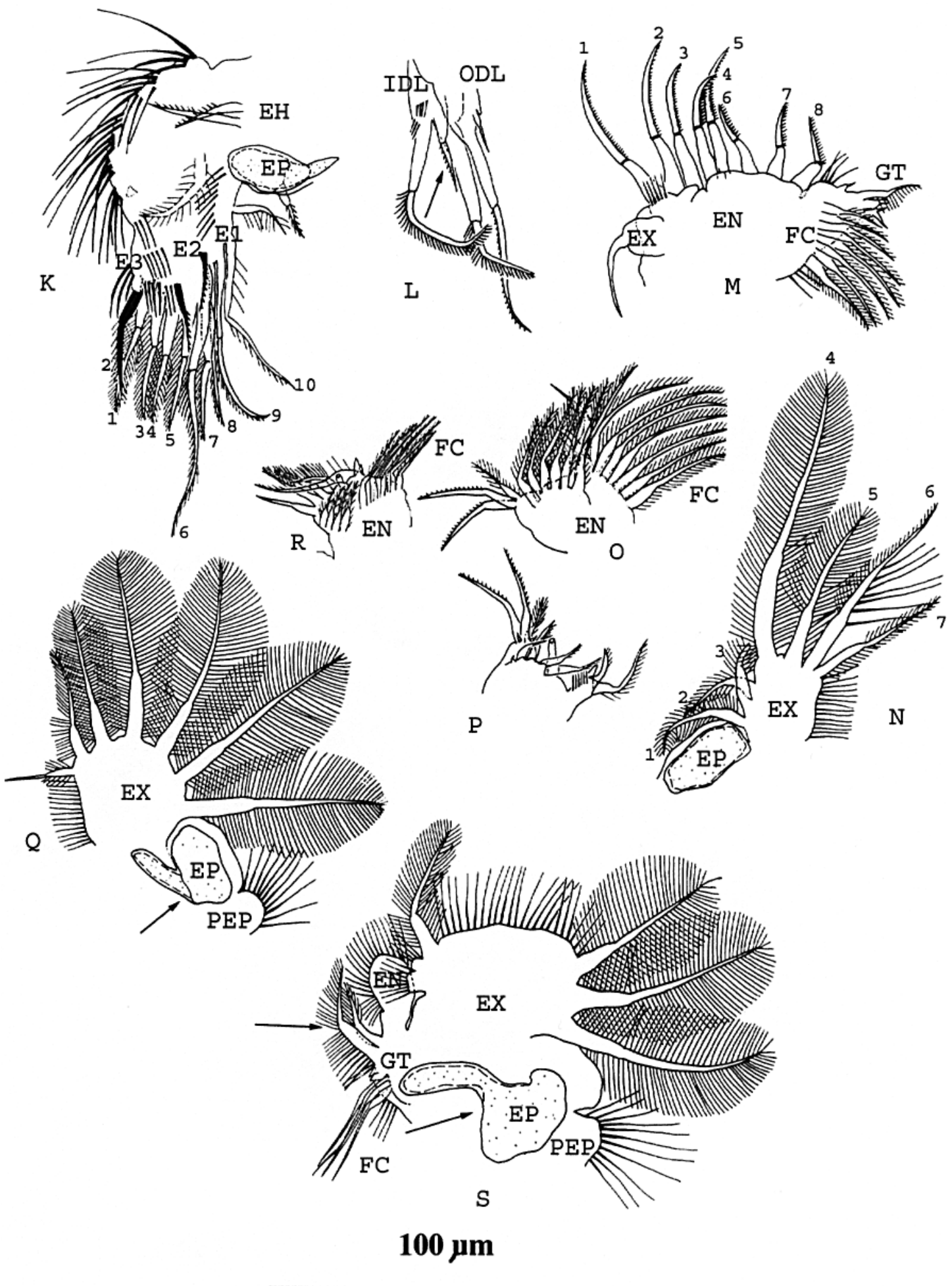

Fig. 3b. Pleuroxus toumodensis. Female: first limb (K), ODL-IDL (L), second limb (M), third limb exopodite (N), endopodite $(\mathrm{O}, \mathrm{P})$, fourth limb, exopodite $(\mathrm{Q})$, endopodite $(\mathrm{R})$, fifth limb (S). 


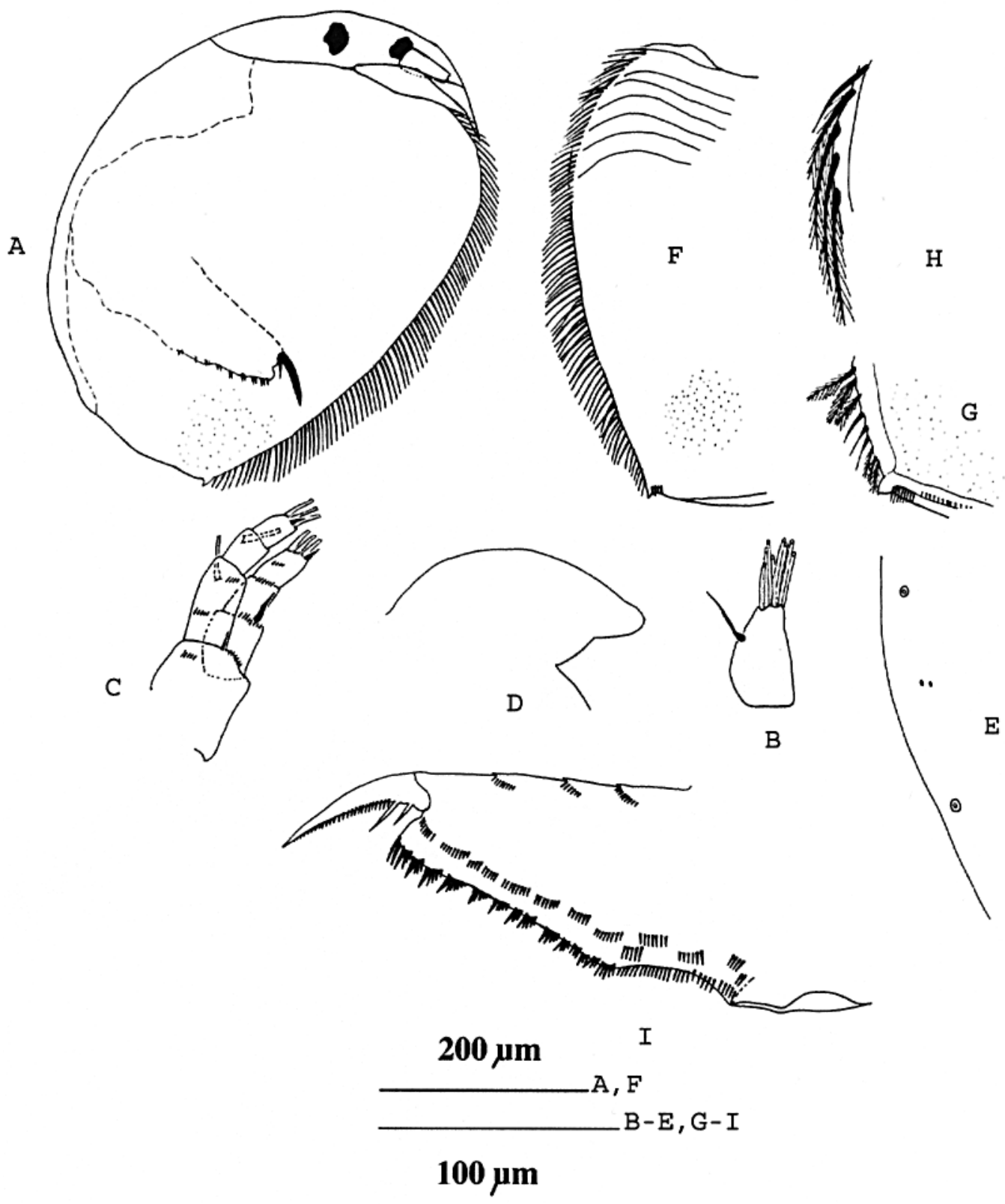

Fig. 4a. Pleuroxus unispinus. Female: habitus (A), first antenna (B), second antenna (C), labrum (D), headshield (E), ventral margin $(\mathrm{F})$, postero-ventral corner $(\mathrm{G})$, antero-ventral corner $(\mathrm{H})$, postabdomen $(\mathrm{I})$.

middle of rostrum, directed downward, provided with nine terminal aesthetascs; no peg at base. Lateral seta arising from obscure tubercle about a third distance from tip and about as long as longest aesthetasc.

Antenna 5 (Figure $4 \mathrm{C}$ ): as for genus.
Valves (Figure 4 F, H): Dorsal and ventral margins convex; dimples on postero-ventral portion; posterior margin slightly convex; postero-dorsal angle not well demarcated; ventral margin with 85-90 plumose setae.

Postabdomen (Figure 4 I): Slightly narrowing distally; distal margin truncated, anal margin slightly conca- 
ve and with row of teeth; post-anal margin long and with twelve anal teeth diminishing proximally each with group of spinules; lateral surface with row of ten fascicles; three transverse crescents of spinules across ventral margin.

Terminal claw (Figure 4 I): long and with two basal spines, distal much longer than proximal and about four times shorter than claw; pecten of spinules along entire dorsal concave surface.

Size: length: $0.51 \mathrm{~mm}$; height: $0.36 \mathrm{~mm}$.

\section{B. Trunk limbs}

Trunk limb 1 (Figure 4 J, K): Proportions of IDL as in $P$. aduncus, but length of setae of endites much more variable. Thus, Seta 5 much shorter than seta 7, but also shorter than seta 4 , while seta 9 longer than seta 10 .

Trunk limb 2 (Figure 4 L): Scraper 2 shorter than scraper 1 and scraper 6 longer than scrapers 7 and 8 , with 7 the shortest of the three. A small receptor between scrapers 5 and 6 . Seta 8 of gnathobasic filtercomb shortened.

Trunk limb 3 (Figure 4 M): Exopodite setae 4 and 6 articulated at same level; seta 5 constricted much further basad.

Trunk limb 4 (Figure $4 \mathrm{~N}$ ): Epipodite as in P. toumodensis.

Trunk limb 5 (Figure 4 O): Epipodite as in P. toumodensis; endopodital seta shorter than gnathobasic seta.

\section{Pleuroxus cf. similis (Vavra 1900) (Figure 5)}

Material examined: One partly degraded parthenogenetic female from river Mvoulikinde along footpath from Adjap village to Bifa village, Campo-Ma'an forest, 09/08/01. Morphological analysis hence incomplete.

Diagnosis: Denticles present at postero-ventral angle of valves (1-3); postabdomen with anal teeth characteristically gradually diminishing proximally.

\section{A. External features}

Postabdomen (Figure $5 \mathrm{H}$ ): Elongated, slightly tapering distally; anal margin slightly concave and with row of teeth; post-anal margin long, with eighteen spines grouped and characteristically gradually diminishing proximally, longest at dorsal-distal corner; about eight fascicles of setules laterally; three transverse crescents of spinules across ventral surface.

Terminal claw (Figure $5 \mathrm{H}$ ): Broad-based and curved distally; with two basal spines distal longer than proximal; dorsal and ventral margins with spinules.

\section{B. Trunk limbs}

Trunk limb 1 (Figure 5 A, B): IDL as in P. denticulatus.

Trunk limb 2: seta 8 of filter-comb shortened as in $P$. unispinus.

Trunk limbs 3-4: no information. Trunk limb 5: endopodal seta much smaller than gnathobasic seta.

6. Pleuroxus laevis (Sars 1862) (Figure 6)

Material examined: Three parthenogenetic females from community fish ponds at Nguti village, Korup forest, 23/06/99; one parthenogenetic female from Lake Barombi Mbo, Kumba, Bakundu forest, 28/07/2000.

Diagnosis: Body elongated, postabdomen long and slightly bent; posterior ventral setae submarginal; IDL with first two setae similarly long; spine very short. Scraper 6 of P2 longer than scrapers 7 and 8. Sensillum behind scraper 5. P3: External spines on outer portion of endopodite very long and unequal in length. Seta 4 of exopodite not clearly constricted. P4-P5: epipodites without fingers.

\section{Description}

\section{A. External features}

Head (Figure 6 A): Rostrum long, sharply pointed; eye elongate to margin of head-shield, about half diameter from margin; ocellus smaller than compound eye, located about a third distance from eye to tip of rostrum; head-shield with two major pores and two minor pores close to each other about midway; post-pore distance about one and half times inter-pore distance.

Labrum (Figure 6 D): Triangular, weakly convex anteriorly, with nipple-like apex; weakly concave immediately posterior.

Antennule (Figure 6 B): Short, broad, not reaching about halfway tip of rostrum; without peg and with nine terminal aesthetascs; lateral seta arising from prominent tubercle about a sixth distance from tip and far longer than aethetascs.

Antenna (Figure $6 \mathrm{C}$ ): as for genus.

Valves (Figures 6 F, H): Ventral margin convex and with 85-90 plumose setae, anterior implanted in indentations of anterior margin; postero-ventral slightly submarginal; postero-ventral corner with single denticle followed by row of spinules, first two barely projecting beyond valve margin; posterior margin almost straight.

Postabdomen (Figure 6 I): Long; narrowing distally, 

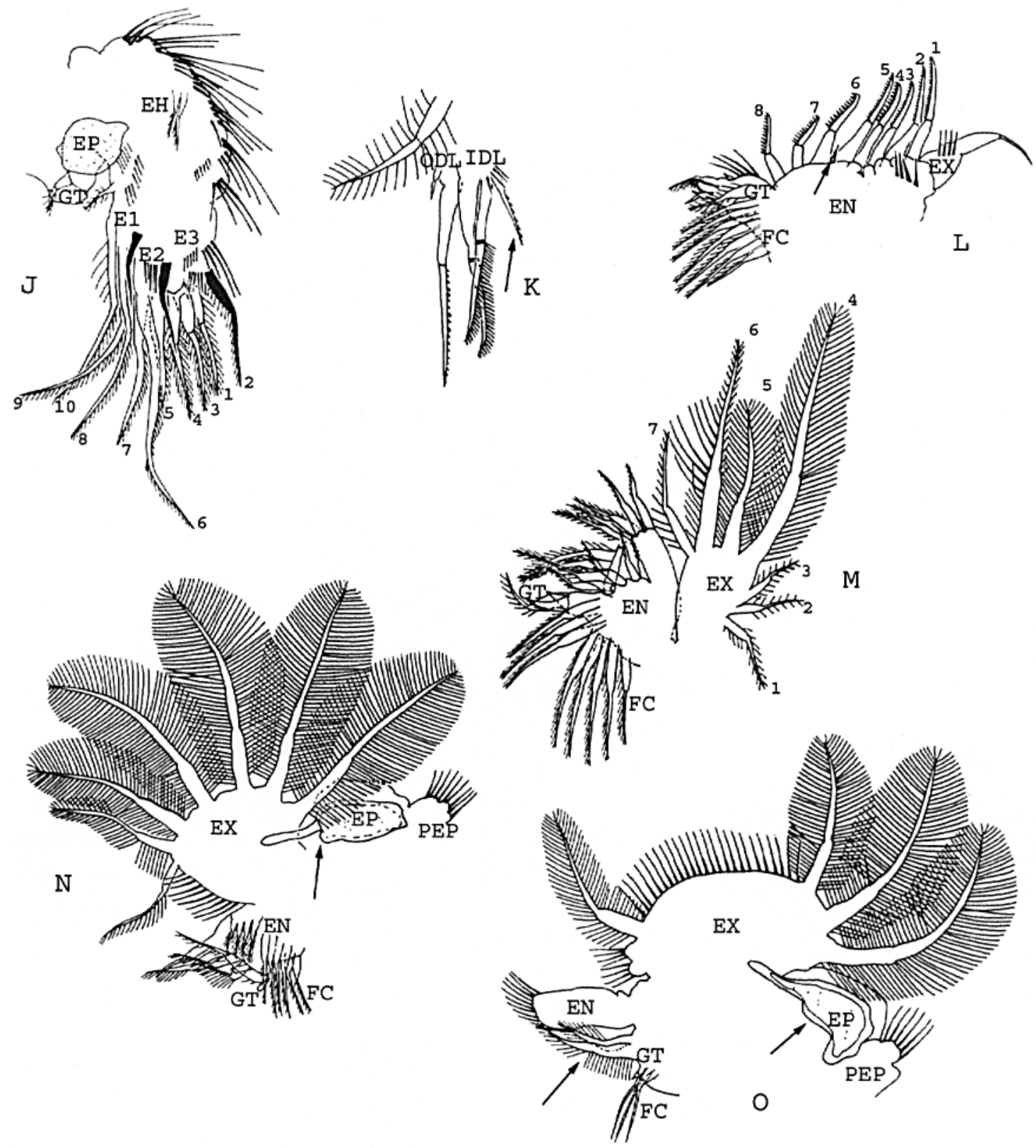

$100 \mu \mathrm{m}$

$\mathrm{J}, \mathrm{K}, \mathrm{M}-\mathrm{O}$

L

Fig. 4b. Pleuroxus unispinus. Female: first limb (J), ODL-IDL (K), second limb (L), third limb (M), fourth limb (N), fifth $\operatorname{limb}(\mathrm{O})$. 


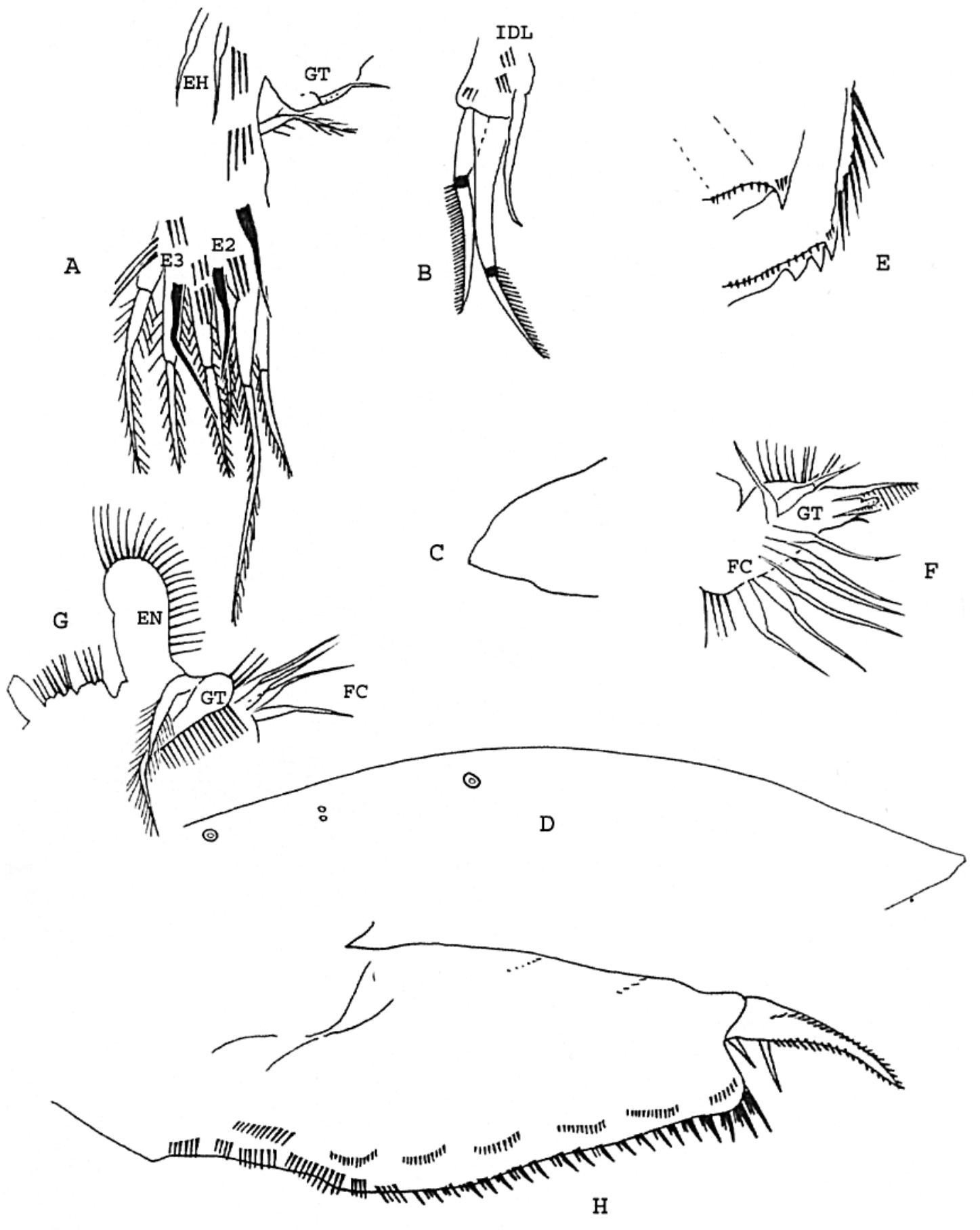

$100 \mu \mathrm{m}$

Fig. 5. Pleuroxus cf. similis. Female: E2, E3 of First limb (A), IDL (B), labrum (C), headshield (D), postero-ventral corner (E), gnathobase of second limb $(\mathrm{F})$, endopodite of fifth limb $(\mathrm{G})$, postabdomen $(\mathrm{H})$. 
slightly curved; dorsal and ventral margins almost straight, widest at pre-anal angle; anal teeth small and distal teeth larger than others; lateral surface with row of eight fascicles of spinules along post-anal section; anal groove with continuous row of spinules that reach pre-anal corner; three crescents of spinules across ventral surface.

Terminal claw (Figure 6 I): Long, gently curved to sharp tip and with two basal spines; first short and second a quarter length of claw; claw with spinules along entire dorsal concave surface.

Size: length: $0.66 \mathrm{~mm}$; height: $0.38 \mathrm{~mm}$.

\section{B. Trunk limbs}

Trunk limb 1 (Figure $6 \mathrm{~J}, \mathrm{~K}$ ): spine of IDL shorter than first segment of long setae, about as long as spine of ODL; setae 1 and 2 about similarly long; setae 5 and 7 of E2 about equally long.

Trunk limb 2 (Figure 6 L): Scrapers 1-2 the same length with decreasing lengths towards gnathobase; scraper 6 longer than 7 and 8; the latter equally long. Sensillum at base of scraper 5; otherwise as for genus.

Trunk limb 3 (Figure 6 M, N): Exopodital seta 5 apparently not constricted; outer portion of endopodite with two long spines (longer than setae 1-3 of exopodite; in all other species found, these spines shorter than setae 1-3 of exopodite), the outer one longer than the inner.

Trunk limb 4 (Figure 6 O, P): Endopodite: outer spine robust; Epipodite without process, otherwise as for genus.

Trunk limb 5 (Figure 6 Q): Epipodite roughly oval; endopodital seta smaller than gnathobasic seta.

\section{Discussion}

As it turns out, the Cameroon rainforest Pleuroxus can be distinguished by the shape and ornamentation of the postabdomen, but also by a host of characters found on the trunk limbs, such as the relative dimensions of setae of the inner distal lobe (IDL), endites (E3-E1), scrapers of second limb (P2), exopodite setae of third limb (P3), epipodite processes fourth and fifth limbs (P4/P5), endopodital/gnathobasic setae P5 and presence or absence of sensillae on the endopodite of P4. It is almost certain that a deeper investigation of the fine structures on the endopodites of P3 and P4 would yield even more distinctive characters, but at least an exploratory study by SEM would be needed for this, and such a study requires a more abundant material than we had at hand.
Not much literature is available that documents that limb structure of Pleuroxus species. For a comparison, we mainly relied on Alonso's (1996) book, which includes $P$. aduncus, denticulatus and laevis. In general, Alonso's detailed figures correspond well with the trunk limb characters we describe, providing us with a degree of confidence in their stability.

With regard to Frey's (1993a, b) attempt to subdivide the genus Pleuroxus in (sub)genera, one of which, Picripleuroxus, is here represented by the species laevis, denticulatus, and similis, we come to the conclusion that no support for such a subdivision is found in trunk limb morphology. In fact $P$. laevis clusters with no other species in particular except perhaps the little known unispinus, while $P$. denticulatus and $P$. similis share a number of micro-characters, but $P$. laevis also shares other features with aduncus. A deeper insight into the phylogeny of Pleuroxus will thus have to await scrutiny of the trunk limbs of more species.

From a biogeographic point of view, it is now clear that this genus is well represented in the tropics and not restricted only to two or three species as claimed by Fernando (1980). However, the abundances of individual species are low to very low. This presumed rarity might have been ascribed to an insufficient sampling effort, but the present intensive investigation clearly rules that out. Four of the Pleuroxus species recorded here abound in bogs of the forest and tundra zones of Western and Northern Europe, Northern Asia and North America, characterized by few species of coniferous trees (if any), cool temperatures, waterlogged soils and slow decomposition rates, resulting in the accumulation of peat and humic acids. Such peaty environments also occur in the Cameroon rainforest, but are much less predator-free here than in the temperate and subarctic zones (Chiambeng \& Dumont, submitted). Also, in the temperate zone, chydorids come and go in a sequence that is dictated by the seasons, temperature and photoperiod perhaps being the most important factors. Such a partition of time is not possible in the tropics: all species are active all the time, and thus competition between them is exacerbated, relentless, and of a permanent nature. The combined effects of competition and predation, not climate, therefore explain the rarity of these so-called «temperate zone » species in the tropics. They probably occur almost everywhere in the rainforest, but are hard to observe. Males were not seen, and this may not be a coincidence either, since crowding elicits their presence, but crowded populations hardly ever occur.

While four species are thus Eurosiberian, or show an even wider range of distribution, one (P. toumodensis) 


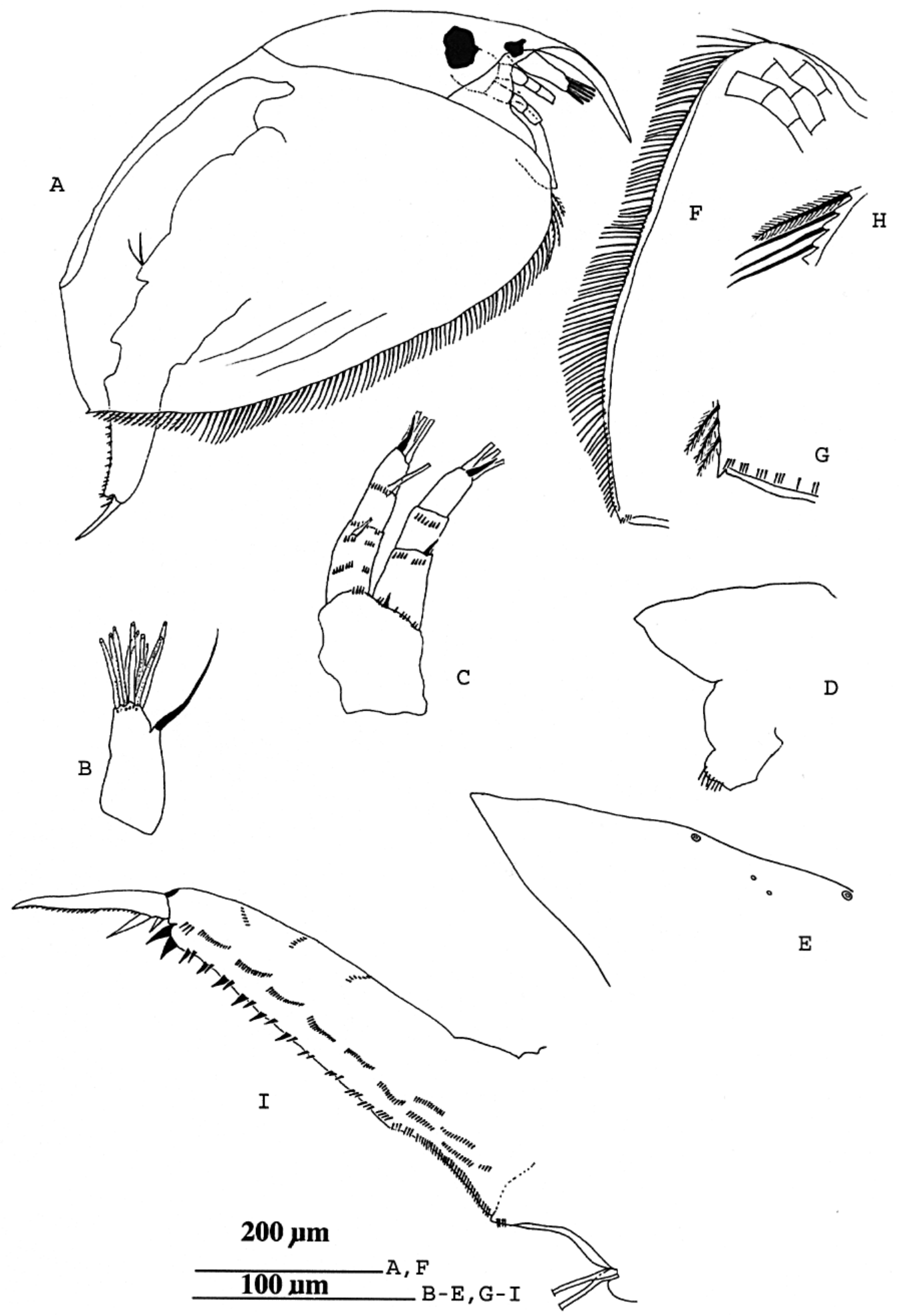

Fig. 6a. Pleuroxus laevis. Female: habitus (A), first antenna (B), second antenna (C), labrum (D), headshield (E), ventral margin of valves $(\mathrm{F}, \mathrm{H})$, postero-ventral corner $(\mathrm{G})$, postabdomen $(\mathrm{I})$. 


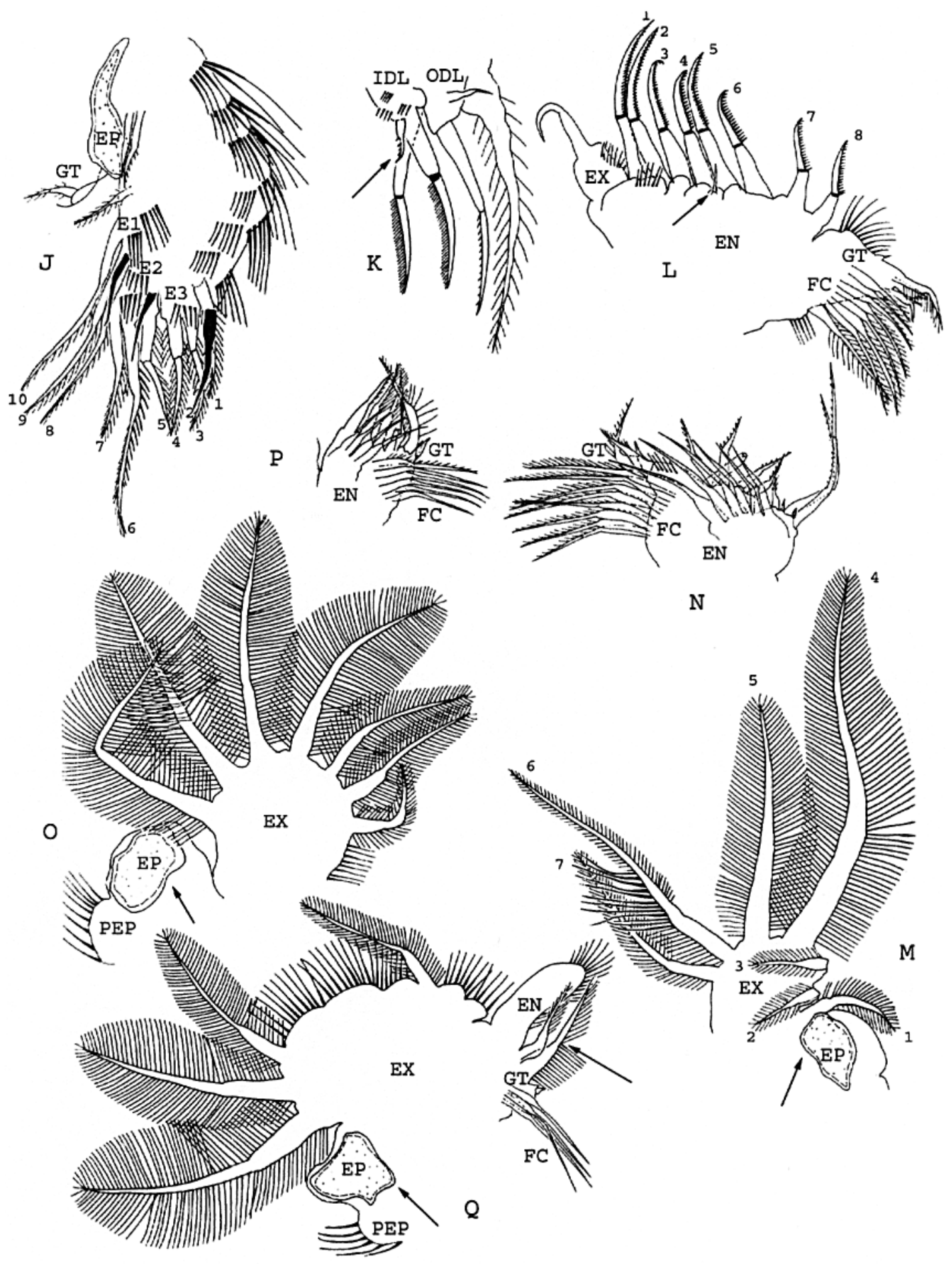

$100 \mu \mathrm{m}$ $\mathrm{J}-Q$

Fig. 6b. Pleuroxus laevis. Female: first limb (J), ODL-IDL (K), second limb (L), third limb exopodite (M), endopodite (N), fourth limb exopodite $(\mathrm{O})$, endopodite $(\mathrm{P})$, fifth limb $(\mathrm{Q})$. 
is an African endemic, found mostly in West Africa, living in gallery forest waters along rivers from the $\mathrm{Ni}$ ger to the Nile (Smirnov 1971). It is now also shown to occupy true rainforest. Pleuroxus unispinus had to date been found only in Australia (Vavra 1900, Smirnov 1996). In our morphological analysis, we came out sufficiently close to this species to assume that it really lives in Africa too. The total number of Pleuroxus species known to occur in the rainforest is thereby raised to seven.

\section{Acknowledgements}

The first author thanks the Belgian Technical Cooperation (BTC) for the scholarship award that resulted in securing these results, and the Director of the Institute for Agricultural Research for Development (IRAD), Cameroon, for releasing him for the time allocated to this study.

\section{References}

Alonso M. 1996. - Crustacea Branchiopoda. Fauna Iberica 7. Museo Nacional de Ciencias Naturales, Consejo Superior de Investigationes Cientificas, Madrid.

Chiambeng G.Y. 2004. - Rainforest Branchiopoda (Crustacea: Anomopoda, Ctenopoda and Cyclestherida) of Cameroon, Gulf of Guinea, Central Africa. Ph.D thesis, Ghent University, Belgium, 307pp.
Dumont H. J. \& Negrea S. 2002. - Introduction to the Class Branchiopoda. Guides to the Identification of the Microinvertebrates of the Continental Waters of the World 19. Backhuys, Leiden.

Fernando C. H. 1980. - The species and size composition of Tropical Freshwater Zooplankton with special reference to the Oriental region (South East Asia). Int. Rev. gesam. Hydrobiol., 65, 411-426.

Frey D.G. 1988. - Are there Tropicopolitan Macrothricid Cladoceran? Acta Limnol. Brazil., 11, 513-525.

Frey D.G. 1993a. - Subdivision of the Genus Pleuroxus (Anomopoda, Chydoridae) into subgenera worldwide. Hydrobiologia, 262, 133-144.

Frey D.G. 1993b. - Species of Pleuroxus (Anomopoda, Chydoridae) from the subantarctic islands and southernmost South America: a partial unraveling of the Pleuroxus aduncus problem. Hydrobiologia, 262, 145-188.

Smirnov N.N. 1971. - Chydoridae fauny mira. Fauna SSSR 1, 2 (n.s. 101), Leningrad. (English translation: Jerusalem, 1974).

Smirnov N.N. 1996. - Cladocera: The Chydorinae and Sayciinae (Chydoridae) of the world. in H.J. Dumont (ed.). Guides to the Identification of the Microinvertebrates of the Continental Waters of the World, 11, 197 pp. SPB Academic, The Hague.

Vavra W. 1900. - Süsswasser-Cladoceren Hamburger Magalhaenische Sammelreise. Herausgegeben vom Naturhistorischen $\mathrm{Mu}$ seum zu Hamburg, 5, 1-25. 